\title{
The Effect of Different Wavelength of Light for Microbial Fuel Cell with an Anode of Rhodopseudomonas faecalis (PSB-B)
}

\author{
Guang Rong, Qingping Hu* \\ College of Life Science, Shanxi Normal University, Linfen, China \\ Email: *hqp72@163.com
}

How to cite this paper: Rong, G. and $\mathrm{Hu}$, Q.P. (2017) The Effect of Different Wavelength of Light for Microbial Fuel Cell with an Anode of Rhodopseudomonas faecalis (PSB-B). Open Access Library Journal, 4: e3389.

https://doi.org/10.4236/oalib.1103389

Received: January 19, 2017

Accepted: February 19, 2017

Published: February 22, 2017

Copyright $\odot 2017$ by authors and Open Access Library Inc.

This work is licensed under the Creative Commons Attribution International License (CC BY 4.0).

http://creativecommons.org/licenses/by/4.0/

\begin{abstract}
A microbial fuel cell (MFC) with an algae-assisted cathode is a low-cost and sustainable way to provide the oxygen for the oxygen reduction reaction. The anode was with anaerobic microorganism, a kind of photosynthetic bacteria (PSB-B). An algae bioreactor was connected to cathode microbial fuel cells to increase power generation by supplying more oxygen to cathode electrode. In this study, we used red, blue and white LED light as the light source, and the anode and cathode were under irradiation respectively. The result showed that white LED light was an effective factor for the anode, the cell voltage was built up from $34 \mathrm{mv}$ to $60 \mathrm{mv}$, power density increased up to $2.5 \mathrm{~mW} / \mathrm{m}^{2}$, the red and blue light had positive impact on the voltage. At cathode, the voltage was almost on steady stage conditions, and it was fluctuated around $35 \mathrm{mv}$ by oxygen bubbles that were produced by algae. This relatively simple method increased the oxygen reduction rate at a low cost and could be applied to improve the performance of MFC.
\end{abstract}

\section{Subject Areas \\ Microbiology}

\section{Keywords}

Microbial Fuel Cell, Light, Photosynthetic Bacteria

\section{Introduction}

Electricity generation with the bacteria as catalyst the MFC anode is a special, environmental way. It was a kind of bioelectrochemical system that can generate electricity by active bacteria [1]. A sediment microbial fuel cell has the advantage of maintenance-free operation, long-term power generation as a power source 
[2]. Although the MFC concept has been known for a long time, the technology is still at an early research stage [3]. Currently, the world is confronting with the challenges of high energy demand and higher fuel prices. In order to cope with these challenges, researchers have paid more attention to find sustainable and cost-effective methods of energy production. MFC offers tremendous potential to produce energy in the form of electricity [4].

MFC is composed of anode and cathode. At anode, electrons are liberated by the organic compounds oxidizing. These electrons move through to the cathode. At cathode, electrons combine with an electron acceptor. The chemical energy of substrates can be transformed into electrical energy by the metabolic activity of microorganisms. Recently, some researchers have found microbial technology for wastewater nutrients treatment using MFC providing a novel, efficient and cost-effective solution for increasing the concentration of oxygen at the cathode. The anode chamber was full of a medium containing a synthetic wastewater [5] with the components and concentrations. Therefore, it could also be a promising approach to treat wastewater containing high COD [6]. However, the performance of MFC was affected by many factors, such as anode and cathode materials, substrates, reactor structure and others [1]. In this study, we have proposed to use algae and photosynthetic bacteria biomass as a substrate for high power output. PSB-B was preserved College of Life Science Microbiology Laboratory, Shanxi Normal University. It was separated from the silt in Fen River and identified by 16 sDNA sequence analysis as a kind of Rhodopseudomonas. The PSB-B required light with a certain wavelength for energy production under anaerobic conditions. PSB has been shown to be safe and non-toxic, rich in nutrients featuring unique biological transformation functions. It was being widely studied in renewable energy field because of high efficiency of hydrogen production, and high degradation rate of organic matter [7].

This research used a different signal acquisition system and special software of signal collection. It could show the potential changes during a short period and could help us to discover the little changes and convenient for analysis. The multimeter was not accurate for the tiny cell voltage observation, it could not be observed visually for the change in a short period.

\section{Materials and Methods}

\subsection{Microbial Fuel Cell Configuration and Operation}

MFC reactors comprised $11 \mathrm{~mL}$ anode chambers and $11 \mathrm{~mL}$ cathode chambers, separated by a proton exchange membrane (PEM). In this study, the anode and cathode were irradiated with different light sources severally. The anode was made of carbon cloth. Characteristics of the carbon cloth included thickness of $360 \mu \mathrm{m}$, the active area of each material was $14 \mathrm{~cm}^{2}\left(7 \mathrm{~cm}^{2} \times 2\right)$ and area of 90 $120 \mathrm{~cm}^{2} / \mathrm{g}$, served as electrode material [8]. The effective volume of the anodic chamber was $11 \mathrm{~mL}$, using a proton exchange membrane with high ion exchange capacity and low electronic conductivity to separate the electrodes. Both electrodes were connected by an external resistance of $1000 \Omega$. In anode, the carbon 
cloth was an excellent conductor [9]. Carbon cloth coated with Platinum with a surface area of $28 \mathrm{~cm}^{2}$ was used as cathode. A cube type cathode MFC made of plexiglass with a cover arrangement was used in this study.

\subsection{Culture of Algae and Microorganism}

In the start-up of MFC reactor, anode was filled with bacterial culture suspension of PSB-B. PSB-B was cultured at $35^{\circ} \mathrm{C}$ for 3 days. Culture medium: peptone $0.2 \%$, yeast extract $0.2 \%, \mathrm{CH}_{3} \mathrm{COONa} \cdot 3 \mathrm{H}_{2} \mathrm{O} \quad 0.2 \%, \mathrm{MgSO}_{4} \cdot 7 \mathrm{H}_{2} \mathrm{O} 0.02 \%, \mathrm{NaCl}$ $0.2 \%, \mathrm{NaHCO}_{3} \quad 0.3 \%, \mathrm{~K}_{2} \mathrm{HPO}_{4} 0.05 \%, \mathrm{CaCl}_{2} 0.005 \%$, trace element solution 10 $\mathrm{mL} / \mathrm{L}[10]$. Trace element solution: $\mathrm{H}_{3} \mathrm{BO}_{3} 0.7 \mathrm{~g}, \mathrm{MnSO}_{4} \cdot \mathrm{H}_{2} \mathrm{O} 0.4 \mathrm{~g}, \mathrm{ZnSO}_{4} \cdot 7 \mathrm{H}_{2} \mathrm{O}$ $0.06 \mathrm{~g}, \mathrm{Cu}\left(\mathrm{NO}_{2}\right)_{2} \cdot 3 \mathrm{H}_{2} \mathrm{O} 0.01 \mathrm{~g}, \mathrm{pH}=7$.

Before packing into the chambers, the carbon cloth electrodes were submerged in $1 \mathrm{~N} \mathrm{HCl}$ for $24 \mathrm{~h}$, washed with deionized water, then submerged in $1 \mathrm{~N}$ $\mathrm{NaOH}$ for $24 \mathrm{~h}$ and finally washed several times in deionized water [11]. Anode was completely submerged by it; copper wires were used for contact with the external circuit [12]. A fix external resistance $(1000 \Omega)$ was used to facilitate the comparison of the electricity production in different treatments.

A glass bottle was used as an algae (Spirulina platensis, saved in College of Life Science Cytology Laboratory, Shanxi Normal University) bioreactor with a working volume of $220 \mathrm{~mL}$ and $30 \mathrm{~mL}$ head space (BG11 medium), the algae was cultured at $25^{\circ} \mathrm{C}$ for 15 days ( $0.8 \mathrm{~g} / \mathrm{L}$ algae dry biomass).

\subsection{Data Acquisition}

In this study, the MFC reactor was continuously operated at a room temperature of $25^{\circ} \mathrm{C}$. The wavelength of red: $610-620 \mathrm{~nm}$, blue: $465-485 \mathrm{~nm}$, white light is a hybrid of light. Here, we used a signal acquisition device (NI USB-6008), it could acquire 1000 signals a second. The input resolution: 12, max sampling rate: 10 $\mathrm{kS} / \mathrm{s}$, working voltage: $\pm 10 \mathrm{v}$. It was connected with the computer and it could record all data conveniently.

\section{Results and Discussion}

\subsection{Effect for Cell Voltage}

The anode MFC generated a voltage around $60 \mathrm{mV}$ with suspension of PSB-B at the beginning, there was a potential sliding direction with no light. The FMC could generate electricity during the dark period, algae consume oxygen to oxidize the organic matter previously created to obtain energy. In this way, during the dark period, oxygen is consumed by the respiration of algae and reduction reactions which take place in the cathodic chamber [13]. Power density is another critical indicator that evaluates the MFC system performance [14]. As shown, the highest voltage was about $0.064 \mathrm{v}$ and decreased by twenty percent six hours later. During the light period, algae carry out photosynthesis, using carbon dioxide and light to produce organic matter and biomass, it was a fluctuation and rising curve. The maximum voltage was around $0.6 \mathrm{v}$ in $300 \mathrm{~min}$, it was eighty percent higher than the initial. The $\mathrm{pH}$ changed little and as excepted, the cell 
voltage increased by the oxygen. The only cathode was under light and the illumination intensity was 3500 lux, as shown in Figure 1(a). The cell voltage reached steady state conditions with no light, but increased under the light. The anode chamber was covered from light to prevent the growth of algae [15]. The more power the MFC generates, the more protons and cations are being transported from the anode to the cathode and thus made accessible for photosynthetic organisms. The result demonstrated that light source had an effect on the cell voltage. This phenomenon indicates that the differences in MFC performance may come from the different wavelengths.

Figure 1(b) was about the effect of the cathode, the light source was only for algae, when the light was switched on, the illumination phase started and algae carried out photosynthesis, capturing light and carbon dioxide and releasing oxygen. Thus, it can be observed that dissolved oxygen at the cathode increased and cell voltage also increased [16]. As for photosynthesis, was bubbled into the anodic compartment [17]. These bubbles increased and decreased, at first, the cell voltages of red and white light increased fast, then decreased in one hour. It was fluctuated that oxygen concentrations at the cathode control the overall MFC performance under our operation conditions. This effect was also observed by Strik D.P.B.T.B. et al., who studied a solar energy powered microbial fuel cell.

\subsection{Effect for Power Density}

In Figure 2, as expected, the overall trend was familiar with the cell voltage. The power density $(\mathrm{P})$ was calculated from the measured voltage as $\mathrm{P}=\mathrm{V}^{2} / \mathrm{RA}$, where $\mathrm{A}$ is the projected cathode surface area, $\mathrm{V}$ is the measured voltage, $\mathrm{R}$ is the external resistance and I is the current [18], the highest power density could reach $92.85 \mathrm{~mW} / \mathrm{m}^{2}$. As we can see the white light affected for the power density, it has a great increasing range from Figure 2(a), the power density of red and blue light was higher than control experiment.

\subsection{Signal Frequency}

In order to analyze the characteristics of the signal, we did a simple signal frequency chart, most of the voltages were distributed under $5 \mathrm{~Hz}$. Therefore, the

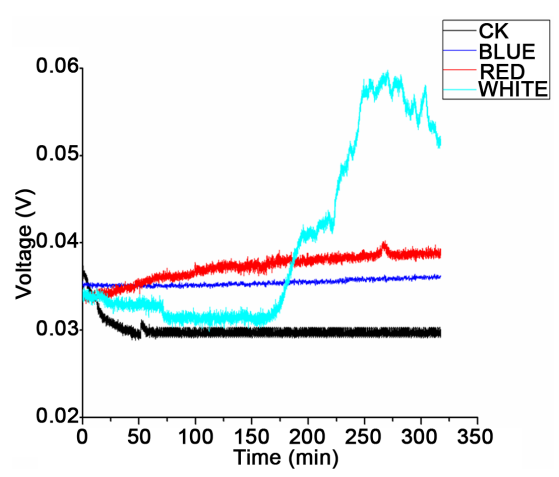

(a)

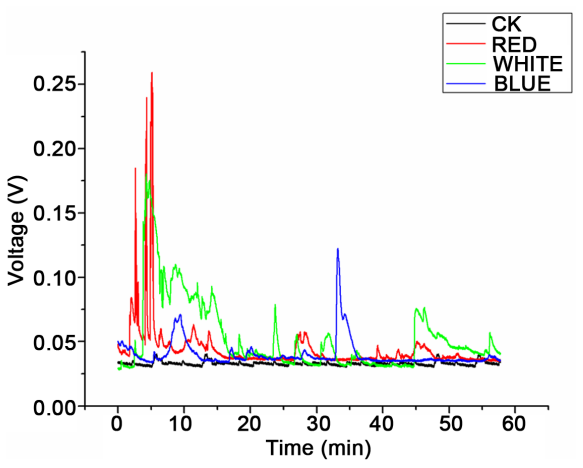

(b)

Figure 1. The effect for cell voltage: (a) light on anode; (b) light on cathode. 
could generate a steady cell voltage and it could be useful for the practical application. In this study, we could find out voltage fluctuation under the red light in Figure 3, the reason might be the photosynthesis of algae that is most active under the red light. In Figure 4, the stray wave of blue light was weakness than others, the red and blue light were with some regular stray wave signal, but the majority of signals were under a low frequency. The result shows that the electrical signal was continuous and stable.

\section{Conclusion}

The microbial fuel cell is a device that converts the chemical energy of organism into electrical energy with the aid of biocatalytic reactions and carried out by microorganisms. The microbial fuel cell with an algae-assisted cathode has been

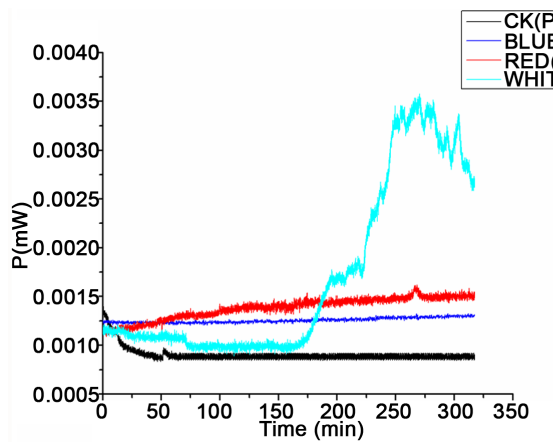

(a)

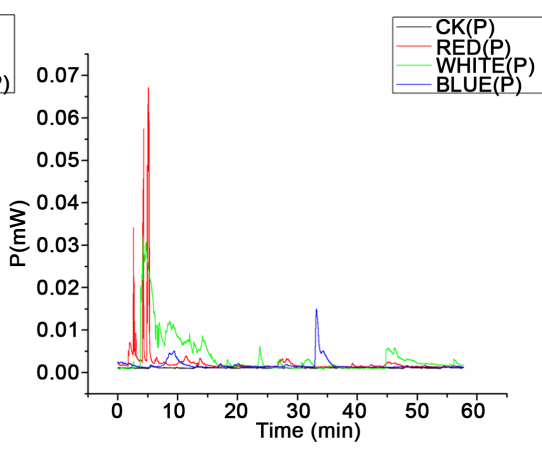

(b)

Figure 2. The effect for power density: (a) light on anode; (b) light on cathode.
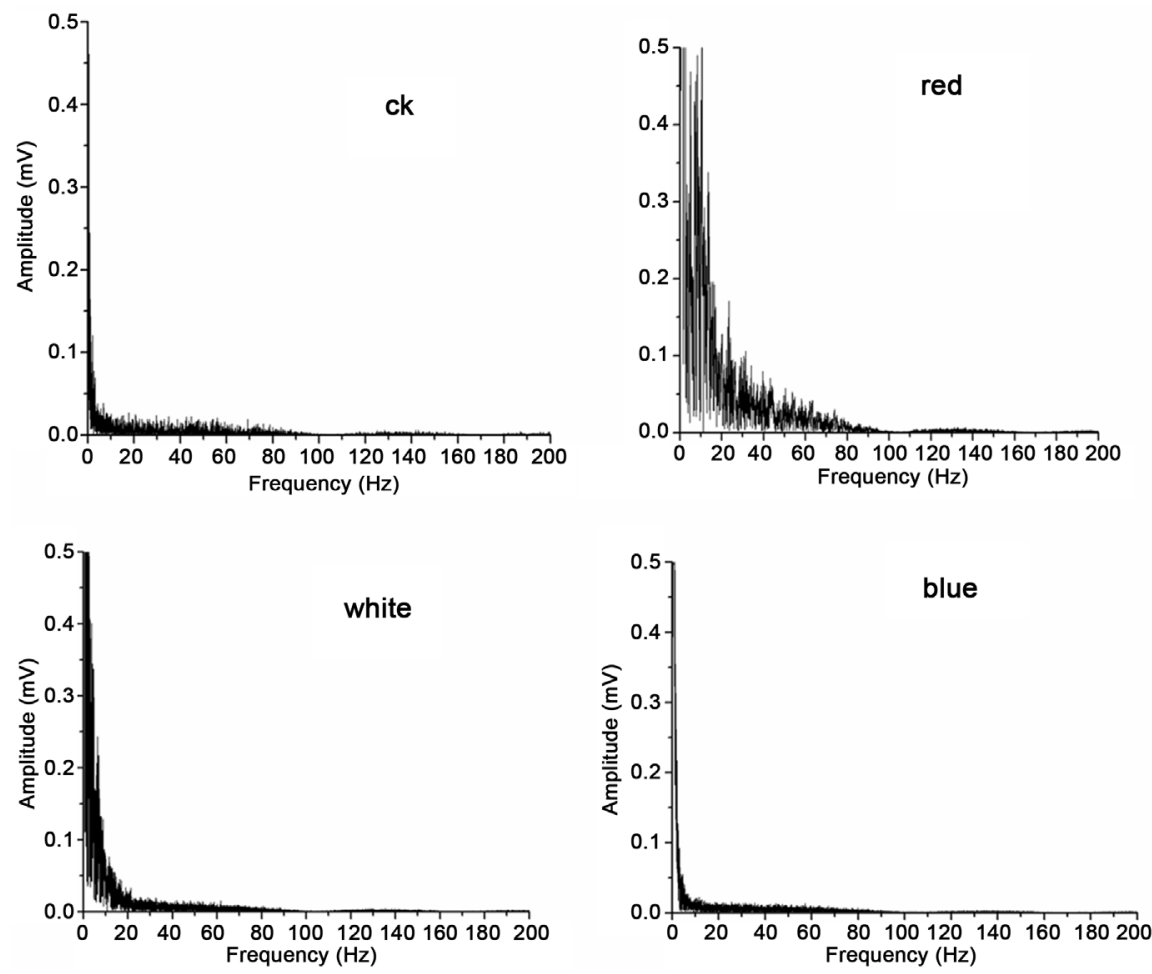

Figure 3. Signal frequency at cathode. 

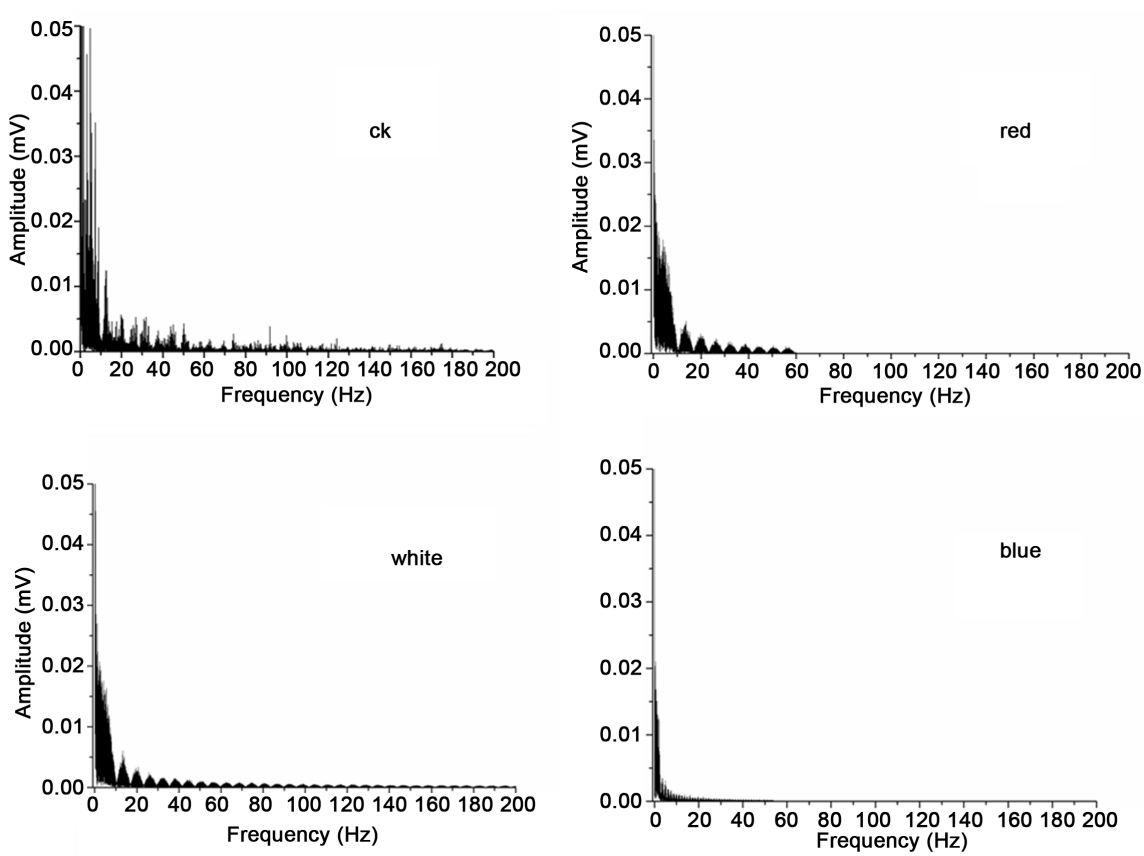

Figure 4. Signal frequency at anode.

provided to voltage $200 \mathrm{mV}$ and kept steady at $30-50 \mathrm{mV}, 0.5-20 \mathrm{~mW} / \mathrm{m}^{2}$. The light source had different effect on anode and cathode. Therefore, a PSB-assisted anode is efficient on generating electricity for MFC.

\section{References}

[1] Xiao, L. and He, Z. (2014) Applications and Perspectives of Phototrophic Microorganisms for Electricity Generation from Organic Compounds in Microbial Fuel Cells. Renewable Sustainable Energy Reviews, 37, 550-559.

https://doi.org/10.1016/j.rser.2014.05.066

[2] Donovan, C., Dewan, A., Heo, D., Lewandowski, Z. and Beyenal, H. (2013) Sediment Microbial Fuel Cell Powering a Submersible Ultrasonic Receiver: New Approach to Remote Monitoring. Journal of Power Sources, 233, 79-85.

https://doi.org/10.1016/j.jpowsour.2012.12.112

[3] Degrenne, N., Buret, F., Allard, B. and Bevilacqua, P. (2012) Electrical Energy Generation from a Large Number of Microbial Fuel Cells Operating at Maximum Power Point Electrical Load. Journal of Power Sources, 205, 188-193.

https://doi.org/10.1016/j.jpowsour.2012.01.082

[4] Pandit, S., Nayak, B.K. and Das, D. (2012) Microbial Carbon Capture Cell Using Cyanobacteria for Simultaneous Power Generation, Carbon Dioxide Sequestration and Wastewater Treatment. Bioresources Technology, 107, 97-102. https://doi.org/10.1016/j.biortech.2011.12.067

[5] Gajda, I., Greenman, J., Melhuish, C., Santoro, C., Li, B., Cristiani, P., et al. (2014) Water Formation at the Cathode and Sodium Recovery Using Microbial Fuel Cells (MFCs). Sustainable Energy Technology Assessment, 7, 187-194. https://doi.org/10.1016/j.seta.2014.05.001

[6] Gajda, I., Greenman, J., Melhuish, C. and Ieropoulos, I. (2013) Photosynthetic Cathodes Formicrobial Fuel Cells. International Journal of Hydrogen Energy, 38, 11559-11564. https://doi.org/10.1016/j.ijhydene.2013.02.111 
[7] Zhang, Z.P., Yue, J.Z., Zhou, X.H., Jing, Y.Y., Jiang, D.P. and Zhang, Q.G. (2014) Photo-Fermentative Bio-Hydrogen Production from Agricultural Residue Enzymatic Hydrolyzate and the Enzyme Reuse. Bioresources, 92, 299-310.

[8] Degrenne, N., Buret, F., Allard, B. and Bevilacqua, P. (2012) Electrical Energy Generation from a Large Number of Microbial Fuel Cells Operating at Maximum Power Point Electrical Load. Journal of Power Sources, 205, 188-193.

https://doi.org/10.1016/j.jpowsour.2012.01.082

[9] Gajda, I., Greenman, J., Melhuish, C. and Ieropoulos, I. (2015) Self-Sustainable Electricity Production from Algae Grown in a Microbial. Biomass and Bioenergy, 82, 87-93. https://doi.org/10.1016/j.biombioe.2015.05.017

[10] De Schamphelaire, L. and Verstraete, W. (2009) Revival of the Biological Sunlightto-Biogas Energy Conversion System. Biotechnology Bioengineering, 103, 296-304. https://doi.org/10.1002/bit.22257

[11] ElMekawy, A., Hegab, H.M., Vanbroekhoven, K. and Pant, D. (2014) TechnoProductive Potential of Photosynthetic Microbial Fuel Cells through Different Con Gurations. Renewable Sustainable Energy Reviews, 39, 617-627.

https://doi.org/10.1016/j.rser.2014.07.116

[12] Behera, M., Jana, P.S. and Ghangrekar, M.M. (2010) Performance Evaluation of Low Cost Microbial Fuel Cell Fabricated Using Earthen Pot with Biotic and Abiotic Cathode. Bioresources Technology, 101, 1183-1189. https://doi.org/10.1016/j.biortech.2009.07.089

[13] Wang, D.B., Song, T.S., Guo, T., Zeng, Q.L. and Xie, J.J. (2014) Electricity Generation from Sediment Microbial Fuel Cells with Algae-Assisted Cathodes. International Journal of Hydrogen Energy, 39, 13224-13230. https://doi.org/10.1016/j.ijhydene.2014.06.141

[14] del Campo, A.G., Cañizares, P., Rodrigo, M.A., Fernández, F.J. and Lobato, J. (2013) Microbial Fuel Cell with an Algae-Assisted Cathode: A Preliminary Assessment. Journal of Power Sources, 242, 638-645. https://doi.org/10.1016/j.jpowsour.2013.05.110

[15] Gajda, I., Greenman, J., Melhuish, C. and Ieropoulos, I. (2015) Simultaneous Electricity Generation and Microbially-Assisted Electrosynthesis in Ceramic MFCs. Bioelectrochemistry, 104, 58-64. https://doi.org/10.1016/j.bioelechem.2015.03.001

[16] Christenson, L.B. and Sims, R.C. (2012) Rotating Algal Biofilm Reactor and Spool Harvester for Wastewater Treatment with Biofuels By-Products. Biotechnology Bioengineering, 109, 1674-1684. https://doi.org/10.1002/bit.24451

[17] Srikanth, S., Kumar, M., Singh, D., Singh, M.P. and Das, B.P. (2016) Electro-Biocatalytic Treatment of Petroleum Refinery Wastewater Using Microbial Fuel Cell (MFC) in Continuous Mode Operation. Bioresource Technology, 221, 70-77. https://doi.org/10.1016/j.biortech.2016.09.034

[18] Singh, A., Nigam, P.S. and Murphy, J.D. (2011) Renewable Fuels from Algae: An Answer to Debatable Land Based Fuels. Bioresource Technology, 102, 10-16. https://doi.org/10.1016/j.biortech.2010.06.032 
Submit or recommend next manuscript to OALib Journal and we will provide best service for you:

- Publication frequency: Monthly

- 9 subject areas of science, technology and medicine

- Fair and rigorous peer-review system

- Fast publication process

- Article promotion in various social networking sites (LinkedIn, Facebook, Twitter, etc.)

- Maximum dissemination of your research work

Submit Your Paper Online: Click Here to Submit

Or Contact service@oalib.com 